\title{
PENGARUH WAKTU KALSINASI TERHADAP SIFAT FISIKA-KIMIA HIDROKSIAPATIT DARI CANGKANG GELOINA COAXANS
}

\author{
Pepi Helza Yanti ${ }^{1}$ dan Yendro Gandi ${ }^{1}$ \\ ${ }^{1}$ Jurusan Kimia, FMIPA, Universitas Riau, Pekanbaru 28293
}

\begin{abstract}
ABSTRAK
Hidroksiapatit (HAp) merupakan salah satu senyawa biokeramik yang digunakan dalam berbagai aplikasi. Pada penelitian ini telah dilakukan sintesis hidroksiapatit (HAp) dengan metode pengendapan menggunakan cangkang lokan (Geloina coaxans) dan $\mathrm{H}_{3} \mathrm{PO}_{4}$ sebagai prekursor. Analisis menggunakan X-Ray Flourocence (XRF) menunjukkan bahwa komposisi kimia utama pada cangkang lokan (Geloina coaxans) adalah CaO. Produk terbaik diperoleh melalui waktu kalsinasi pada suhu $900{ }^{\circ} \mathrm{C}$ selama 180 menit yang ditunjukkan dengan puncak yang memiliki intensitas tertinggi pada $2 \theta=31,7^{\circ}$ dan puncak spesifik lainnya untuk hidroksiapatit pada $2 \theta=$ $32,89^{\circ}, 32,17^{\circ}, 25,86^{\circ}$ dan $49,46^{\circ}$. Difraktogram dibandingkan dengan JCPDS (No 09-0432). Berdasarkan perhitungan menggunakan persamaan Scherrer, didapatkan ukuran kristal dari hidroksiapatit (HAp) adalah 26,62 $\mathrm{nm}$. Analisis menggunakan FTIR juga telah dilakukan untuk mengidentifikasi gugus fungsi pada hidroksiapatit yang diperoleh. Dari spektrum FTIR menunjukkan adanya pita serapan yang khas untuk gugus $\mathrm{OH}^{-}, \mathrm{CO}_{3}{ }^{2-}$ dan $\mathrm{PO}_{4}{ }^{3-}$ pada hidroksiapatit. Morfologi partikel berbentuk granular seperti bola dan gumpalan yang tidak seragam diperoleh melalui analisis menggunakan SEM.
\end{abstract}

Kata kunci: hidroksiapatit, temperatur, morpologi

\begin{abstract}
Hydroxyapatite (HAp) is a bioceramic compound that is used in various applications. In this research, hydroxyapatite (HAp) synthesis has been carried out by precipitation method using Geloina coaxans shell and $\mathrm{H}_{3} \mathrm{PO}_{4}$ as precursors. Analysis using X-Ray Flourocence (XRF) showed that the main chemical composition of Geloina coaxans shell was $\mathrm{CaO}$. The best product was obtained by calcination at $900{ }^{\circ} \mathrm{C}$ for 180 minutes indicated by a peak having the highest intensity at $2 \theta=31.7^{\circ}$ and other specific peaks for hydroxyapatite at $2 \theta=$ $32.89^{\circ}, 32,17^{\circ}, 25.86^{\circ}$ and $49.46^{\circ}$. The difractogram was compared to JCPDS (No 09-0432). Based on calculations using the Scherrer equation, the crystallite size of hydroxyapatite was $26.62 \mathrm{~nm}$. Analysis using FTIR has also been carried out to identify the functional groups of the hydroxyapatite obtained. The FTIR spectrum showed that there were unique absorption bands for $\mathrm{OH}^{-}, \mathrm{CO}_{3}{ }^{2-}$ and $\mathrm{PO}_{4}{ }^{3-}$ groups on hydroxyapatite. Analysis using SEM showed that the morphology was granular like balls and non-uniform aggregate
\end{abstract}

Keywords: hydroxyapatite, temperature, morphology

\section{PENDAHULUAN}

Hidroksiapatit dengan rumus molekul $\mathrm{Ca}_{10}(\mathrm{PO})_{6}(\mathrm{OH})_{2}$ merupakan salah satu biokeramik. Biokeramik dapat didefenisikan sebagai biomaterial berbasis keramik yang dirancang khusus dan disintesis untuk perbaikan dan rekontruksi rangka tubuh, salah satunya digunakan sebagai implan dalam tubuh katalis ataupun adsorben beberapa logam.

Cangkang lokan (Geloina coaxans) merupakan salah satu jenis moluska yang dapat digunakan sebagai prekursor kalsium (Ca) untuk sintesis hidroksiapatit (HAp) karena mengandung kalsium karbonat atau $\mathrm{CaCO}_{3}$ yang dapat diubah menjadi $\mathrm{CaO}$ melalui proses kalsinasi. Di Indonesia penyebaran lokan (Geloina coaxans) terdapat pada beberapa

Korespondensi

Telepon: -

Email: pepihelzayanti@lecturer.unri.ac.id

DOI: https://doi.org/10.35799/cp.13.2.2020.31473 daerah diantaranya adalah Desa Panipahan di Kecamatan Pasir Limau Kapas Kabupaten Rokan Hilir, Riau. Untuk meningkatkan nilai ekonomisnya, cangkang lokan (Geloina coaxans) dapat dimanfaatkan sebagai sumber kalsium (Ca) dalam sintesis Hidroksiapatit (HAp).

Beberapa faktor dapat mempengaruhi hidroksiapatit hasil sintesis. Salah satu faktor penting adalah waktu kalsinasi, hal ini disebabkan karena pada saat kalsinasi akan terjadi transformasi fasa amorf menjadi kristalin.Berdasarkan penelitian sebelumnya,"naiknya suhu kalsinasi dari 800 menjadi $1250^{\circ} \mathrm{C}$ akan mengurangi pembentukan fasa sekunder dan hidroksiapatit (HAp) yang dihasilkan lebih murni (Kamalanathan et al., 2014)". "Abidi dan 
Murtaza (2013) juga telah berhasil melakukan sintesis hidroksiapatit pada temperatur 800$1000^{\circ} \mathrm{C}$ dan menghasilkan hidroksiapatitit dengan ukuran kecil dari $24 \mathrm{~nm}$ ". Penelitian sebelumnya juga menyatakan dengan "kalsinasi $900{ }^{\circ} \mathrm{C}$ telah dihasilkan puncak difraksi yang lebih sempit dengan tingkat kristalinitas yang lebih baik" (Khoo et al., 2015)". Pada penelitian ini pengaruh waktu kalsinasi pada sintesis hidroksiapatit (HAp) dari bahan dasar cangkang lokan (Geloina coaxans) dari Rokan Hilir sebagai sumber kalsium (Ca) dengan $\mathrm{H}_{3} \mathrm{PO}_{4}$ sebagai sumber posfat dipelajari dan dianalisis sifat fisika dan kimianya dengan menggunakan FTIR, XRD dan SEM.

\section{BAHAN DAN METODE}

\section{Alat dan bahan yang Digunakan}

Alat yang digunakan meliputi lumpang, cawan, blender (Philips), peralatan gelas standar laboratorium kimia, furnace (Vulcan ${ }^{T M}$ seri A-130), pH meter (ATC), oven (Gallen kemp), hotplate (Rexim RSH-1DR As One), magnetik stirrer (Spinbar), crucible, neraca analitik (Mettler AE 200), ayakan 200 mesh (W.S Tyler Incorporated U.S.A), X-Ray Flourocence (XRF) (S2 Ranger Burker), Fourier Transform Infra Red (FTIR), X-Ray Diffraction (XRD) (Gbc Emm), Scanning Electron Microscopy (SEM), Bruker.

Bahan yang digunakan pada penelitian ini adalah cangkang lokan (Geloina coaxans), $\mathrm{H}_{3} \mathrm{PO}_{4}$ (Merck), $\mathrm{HNO}_{3}$ p.a (Merck), $\mathrm{NH}_{3}$ (Merck), larutan buffer, kertas saring Whatman 42 dan akuabides.

\section{Preparasi sampel}

Lokan (Geloina Coaxans) dibersihkan, kemudian dikeringkan diudara terbuka dilanjutkan menggunakan oven selama 2 jam dengan suhu $105^{\circ} \mathrm{C}$, setelah kering ditumbuk sampai halus dengan menggunakan lumpang, kemudian diayak dengan menggunakan ayakan yang lolos 200 mesh. Bubuk cangkang lokan (Geloina coaxans) yang telah halus dikalsinasi pada suhu $1000^{\circ} \mathrm{C}$ selama 12 jam, untuk mengkonversikan $\mathrm{CaCO}_{3}$ menjadi $\mathrm{CaO}$. Senyawa $\mathrm{CaO}$ yang dihasilkan dianalisis menggunakan XRF.

\section{Sintesis hidroksiapatit}

Sintesis Hidroksiapatit (HAp) dilakukan dengan mereaksikan $\mathrm{H}_{3} \mathrm{PO}_{4}$ sebagai sumber pospat dan kalsium (Ca) yang berasal dari cangkang lokan (Geloina coaxans) dengan rasio $\mathrm{Ca} / \mathrm{P}$ yaitu 1,67 . Sampel cangkang lokan (Geloina coaxans) dilarutkan dalam $\mathrm{HNO}_{3}$ untuk mendapatkan larutan $\mathrm{Ca}\left(\mathrm{NO}_{3}\right)_{2}$, Kemudian larutan $\mathrm{H}_{3} \mathrm{PO}_{4}$ diteteskan secara perlahan-lahan ke dalam larutan $\mathrm{Ca}\left(\mathrm{NO}_{3}\right)_{2}$. Campuran tersebut diaduk dengan menggunakan hotplate dengan kecepatan 300 rpm pada suhu $30^{\circ} \mathrm{C}$ dan $\mathrm{pH}$ larutan dijaga pada $\mathrm{pH}=10$ dengan penambahan larutan $\mathrm{NH}_{4} \mathrm{OH}$ sebagai pengatur $\mathrm{pH}$ yang diukur dengan menggunakan $\mathrm{pH}$ meter. Campuran diaduk dengan waktu pengadukan 30 menit dan didiamkan pada suhu kamar selama 24 jam setelah itu larutan disaring dengan menggunakan kertas saring Whatman 42. Endapan yang diperoleh kemudian dikeringkan dalam oven pada suhu $105^{\circ} \mathrm{C}$ selama 2 jam kemudian dikalsinasi menggunakan furnace pada temperatur $900^{\circ} \mathrm{C}$ dengan beberapa waktu kalsinasi yaitu 120 dan 180 menit. Sampel yang telah disintesis dianalisis dengan FTIR, XRD dan SEM.

\section{HASIL DAN PEMBAHASAN}

\section{Analisis Komposisi Kimia Cangkang (Geloina Coaxans) setelah kalsinasi \\ Untuk mengetahui komposisi kimia} cangkang lokan (Geloina coaxans) hasil kalsinasi dilakukan analisis menggunakan $X$ Ray Flouresence $(X R F)$. Hasil analisis dapat dilihat pada Tabel 1.

Tabel 1. Analisis komposisi kimia cangkang (Geloina coaxans) hasil kalsinasi menggunakan $X$-Ray Flouresence $(X R F)$

\begin{tabular}{cc} 
Komposisi & Kadar (\%) \\
\hline $\mathrm{CaO}$ & 97.512 \\
$\mathrm{Ag}_{2} \mathrm{O}$ & 0.639 \\
$\mathrm{SiO}_{2}$ & 0.809 \\
$\mathrm{SrO}$ & 0.33 \\
$\mathrm{Al}_{2} \mathrm{O}_{3}$ & 0.314 \\
$\mathrm{Fe}_{2} \mathrm{O}_{3}$ & 0.017 \\
$\mathrm{BaO}$ & 0.01 \\
$\mathrm{ZrO}$ & 0.002 \\
$\mathrm{MnO}$ & 0.001 \\
\hline
\end{tabular}

Berdasarkan analisis terhadap komposisi kimia cangkang lokan (Geloina coaxans) menggunakan X-Ray Floroscence (XRF) 
didapatkan komposisi utama pada cangkang lokan (Geloina coaxans) adalah $\mathrm{CaO}$ $(97.512 \%)$ dan juga terdapat senyawa lain yaitu $\mathrm{Ag}_{2} \mathrm{O}(0,639 \%), \mathrm{SiO}_{2}(0.809 \%), \mathrm{SrO}$ (0.33\%), $\mathrm{Al}_{2} \mathrm{O}_{3}(0.314 \%)$, dan $\mathrm{Fe}_{2} \mathrm{O}_{3}(0.017 \%)$, $\mathrm{BaO}(0,01 \%), \mathrm{ZrO}_{2}(0,002 \%), \mathrm{MnO}(0,001 \%)$. Hasil menunjukkan bahwa cangkang lokan (Geloina Coaxans) mengandung kalsium yang tinggi yang dapat dimanfaatkan menjadi sumber kalsium dalam sintesis HAp.

\section{Sintesis hidroksiapatit dengan variasi waktu kalsinasi}

Penelitian ini untuk mempelajari pengaruh waktu kalsinasi pada sintesis hidroksiapatit pada temperatur $900{ }^{\circ} \mathrm{C}$ selama 120, dan 180 menit. Sumber kalsium yang digunakan pada penelitian ini adalah cangkang lokan (Geloina coaxans) menggunakan asam nitrat $\mathrm{HNO}_{3} 3 \mathrm{M}$ untuk mendapatkan sumber kalium $\mathrm{Ca}\left(\mathrm{NO}_{3}\right)_{2}$ sedangkan sumber fosfat yang digunakan adalah $\mathrm{H}_{3} \mathrm{PO}_{4}$ yang disintesis pada $\mathrm{pH} 10$ dijaga konstan menggunakan $\mathrm{NH}_{4} \mathrm{OH}$. Hasil sintesis dapat dilihat pada Gambar. 1.

Pada Gambar 1. difraktogram XRD menunjukkan puncak atau intensitas tertinggi pada waktu kalsinasi selama 180 menit yang muncul pada $2 \theta=31,7^{\circ}$ menunjukkan adanya puncak spesifik hidroksiapatit (HAp), puncak ini didukung dengan puncak lainnya yaitu pada $2 \theta=32.8^{0}, 32.17^{0}, 25,86^{\circ}$ dan $49,46^{0}$. Hasil ini dibandingkan dengan JCPDS (No. 09-0432). Pada senyawa yang dihasilkan ini juga terdapat senyawa $\alpha$-TCP ( $\alpha$-tricalcium phosphat) yang dibandingkan dengan JCPDS (No 29-0359). dan $\beta$-TCP ( $\beta$-tricalcium phosphate) yang dibandingkan dengan JCPDS (No 29-0359).

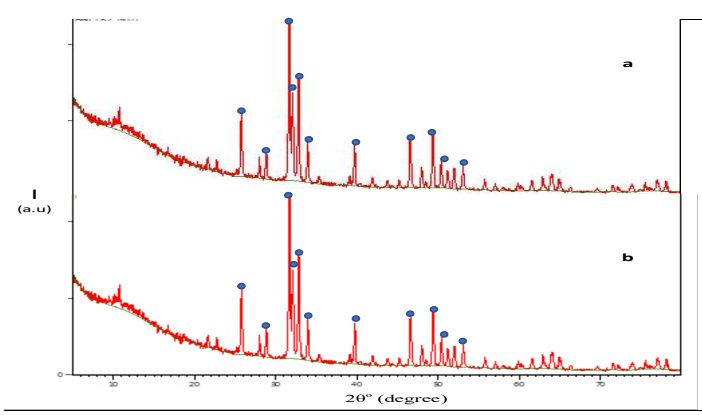

Gambar 1. Difaktogram XRD variasi waktu kalsinasi pada temperatur $900^{\circ} \mathrm{C}$; (a) 120 menit, (b) 180 menit

Berdasarkan variasi waktu kalsinasi yang telah dilakukan pada temperatur $900^{\circ} \mathrm{C}$, waktu kalsinasi selama 180 menit telah menunjukkan waktu lebih baik pembentukan hidroksiapatit (HAp). Presentase hidroksiapatit (HAp) yang di hasillkan adalah $83 \%$ dengan ukuran kristal sebesar 26,62 nm. Hasil analisis ukuran kristal diperoleh melalui perhitungan menggunakan persamaan Scherrer, dengan data yang didapatkan pada analisis difraksi sinar $\mathrm{X}$. Rumus Scherrer yaitu $\mathrm{D}=0,89 \lambda / \beta \cos \theta$, dimana $\lambda$ adalah panjang gelombang $(\mathrm{CuK} \alpha=$ $0,154060 \mathrm{~nm}), \beta$ adalah full width at half maximum (FWHM) dan $\theta$ adalah sudut difraksi XRD. "Peneliti sebelumnya, yaitu Koutsopoulos (2002) juga menyatakan bahwa dari difraktogram XRD puncak hidroksiapatit (HAp) muncul pada $2 \theta=31.80^{\circ}, 32.2^{\circ}$ dan 25.9". "Peneliti lainnya Liu et al. (2016) juga berhasil mensintesis hidroksiapatit dengan puncak utama HAp" Hasil penelitian yang telah dilakukan dapat dijelaskan bahwa waktu pemanasan sangat mempengaruhi kristalinitas senyawa yang dihasilkan. Pada waktu 120 menit juga dihasilkan hidroksiapatit yang ditandai dengan munculnya puncak hidroksiapatit pada $2 \theta=31,7^{\circ}$ dan beberapa puncak pendukung hidroksiapatit lainnya.

\section{Analisis Gugus Fungsi Hidroksiapatit dengan Fourier-Transform Infra Merah (FTIR)}

Untuk mempelajari gugus fungsi dari senyawa hidroksiapatit yang dihasilkan dilakukan analisis menggunakan FTIR. Analisis FTIR dilakukan pada hasil hidroksiapatit (HAp) yang telah disintesis pada waktu 120 dan 180 menit pada $900^{\circ} \mathrm{C}$ dengan prekursor $\mathrm{H}_{3} \mathrm{PO}_{4}$. Hasil analisis FTIR dapat dilihat pada Gambar 2 dan 3 dan Tabel 2 dan 3.

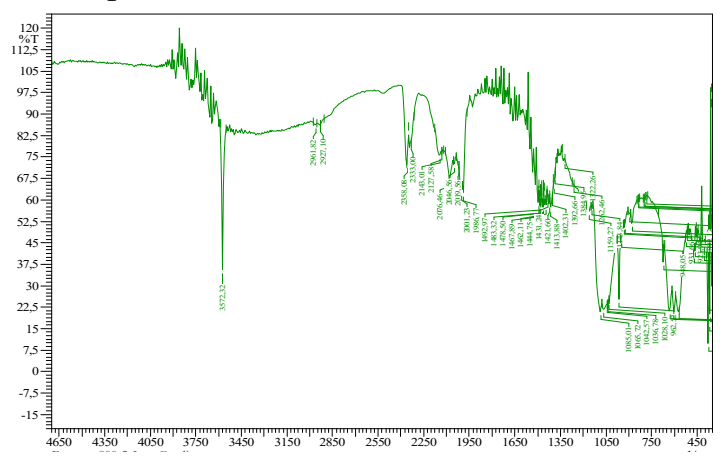

Gambar 2. Spektrum FTIR hidroksiapatit (HAp) dari prekursor $\mathrm{Ca}\left(\mathrm{NO}_{3}\right)_{2}$ dan $\mathrm{H}_{3} \mathrm{PO}_{4}$ kalsinasi $900^{\circ} \mathrm{C}$ selama 120 menit 
Tabel 2. Perbandingan FTIR hidroksiapatit (HAp) hasil sintesis dari prekursor $\mathrm{Ca}\left(\mathrm{NO}_{3}\right)_{2}$ dan $\mathrm{H}_{3} \mathrm{PO}_{4}$ kalsinasi $900^{\circ} \mathrm{C}$ selama 120 menit dengan peneliti sebelumnya.

\begin{tabular}{llll}
\hline \multirow{2}{*}{ Gugus } & \multicolumn{3}{c}{ Pengamatan $\left(\mathrm{cm}^{-1}\right)$} \\
\cline { 2 - 4 } & $\begin{array}{c}\text { Hasil } \\
\text { Penelitian }\end{array}$ & $\begin{array}{l}\text { Chen } \\
\text { et al., 2015 }\end{array}$ & $\begin{array}{l}\text { Shavandi } \\
\text { et al., 2014 }\end{array}$ \\
\hline $\mathrm{O}-\mathrm{H}$ & 3572 & 3567 & 3570 \\
$\mathrm{PO}_{4}$ & 1085 & 1037 & 1100 \\
$\mathrm{PO}_{4}$ & 586 & 567 & 565 \\
$\mathrm{CO}$ & 1444 & 1462 & 1478 \\
\hline
\end{tabular}

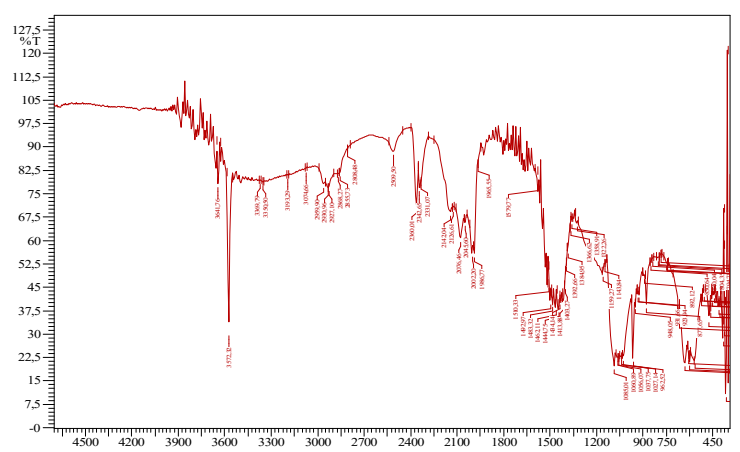

Gambar 3. Spektrum FTIR hidroksiapatit (HAp) dari prekursor $\mathrm{Ca}\left(\mathrm{NO}_{3}\right)_{2}$ dan $\mathrm{H}_{3} \mathrm{PO}_{4}$ kalsinasi $900^{\circ} \mathrm{C}$ selama 180 menit.

Tabel 3. Perbandingan FTIR hidroksiapatit (HAp) hasil sintesis dari prekursor $\mathrm{Ca}\left(\mathrm{NO}_{3}\right)_{2}$ dan $\mathrm{H}_{3} \mathrm{PO}_{4}$ kalsinsi $900^{\circ} \mathrm{C}$ selama 180 menit dengan peneliti sebelumnya

\begin{tabular}{ccll}
\hline & \multicolumn{3}{c}{ Pengamatan $\left(\mathrm{cm}^{-1}\right)$} \\
\cline { 3 - 4 } Gugus & Hasil & \multicolumn{2}{c}{ Referensi } \\
\cline { 3 - 4 } & Penelitian & $\begin{array}{l}\text { Kamalanathan } \\
\text { et al., 2014 }\end{array}$ & $\begin{array}{l}\text { Sofronia } \\
\text { et al., }\end{array}$ \\
& & - & 3014 \\
\hline $\mathrm{O}-\mathrm{H}$ & 3572 & - & 3572 \\
$\mathrm{PO}_{4}$ & 1085 & 604 & 962 \\
$\mathrm{PO}_{4}$ & 931 & 630 \\
$\mathrm{CO}$ & 1444 & 1421 & 1456 \\
\hline
\end{tabular}

Analisis gugus fungsi menggunakan FTIR pada temperatur $900{ }^{\circ} \mathrm{C}$ selama 120 dan 180 menit menunjukkan adanya gugus fungsi posfat $\left(\mathrm{PO}_{4}{ }^{3-}\right)$ dan hidroksil $(\mathrm{OH})$ pada hidroksiapatit hasil sintesis. Spektrum FTIR hasil sintesis hidroksiapatit (HAp) pada temperatur $900^{\circ} \mathrm{C}$ selama 120 menit terlihat pada Gambar 2. sampel memiliki pita serapan fosfat $\left(\mathrm{PO}_{4}{ }^{3-}\right)$ pada bilangan gelombang 962 dan $1085 \mathrm{~cm}^{-1}$. Pita serapan yang muncul pada bilangan gelombang $3572 \mathrm{~cm}^{-1}$ menunjukkan adanya streching $\mathrm{OH}$. Gugus fungsi lainnya yang teramati adalah gugus $\mathrm{CO}_{3}{ }^{2-}$ yang muncul pada bilangan gelombang $1444 \mathrm{~cm}^{-1}$. "Peneliti sebelumnya Chen et al. (2015) juga telah mensintesis hidroksiapatit (HAp) dari limbah cangkang kerang mata tujuh (Abalone shell), hasil analisis FTIR nya menunjukkan adanya gugus fosfat $\left(\mathrm{PO}_{4}{ }^{3-}\right)$ yang muncul pada bilangan gelombang 1037, 960, dan $567 \mathrm{~cm}^{-1}$." Gugus fungsi hidroksil atau $\mathrm{OH}$ juga muncul pada pita serapan di $3567 \mathrm{~cm}^{-1}$. "Peneliti lainnya Shavandi et al. (2014) juga melakukan sintesis hidroksiapatit menggunakan cangkang kerang kepah (Mussel Shell) sebagai sumber kalsium yang menunjukkan adanya pita stretching $\mathrm{OH}$ pada bilangan gelombang 3570 $\mathrm{cm}^{-1}$ dan pita serapan gugus fosfat $\left(\mathrm{PO}_{4}{ }^{3-}\right)$ pada bilangan 603 dan $565 \mathrm{~cm}^{-1}$."

Spektrum FTIR hasil sintesis hidroksiapatit (HAp) pada temperatur $900^{\circ} \mathrm{C}$ selama 180 menit terlihat pada Gambar 3. Senyawa hidroksiapatit (HAp) yang dihasilkan juga memiliki pita serapan fosfat $\left(\mathrm{PO}_{4}{ }^{3-}\right)$ pada bilangan gelombang $931 \mathrm{~cm}^{-1}$ dan $1085 \mathrm{~cm}^{-1}$. Gugus fungsi $\mathrm{OH}$ juga muncul pada bilangan gelombang $3572 \mathrm{~cm}^{-1}$ yang menunjukkan adanya streching $\mathrm{OH}$. "Peneliti sebelumnya Kamalanathan et al. (2014) juga telah membuktikan bahwa pita serapan $\mathrm{PO}_{4}{ }^{3-}$ muncul pada bilangan gelombang $602 \mathrm{~cm}^{-1}$, sedangkan pita serapan dari $\mathrm{OH}$ muncul pada bilangan gelombang $3572 \mathrm{~cm}^{-1}$ ". "Hasil ini sama dengan peneliti sebelumnya Sofronia et al. (2014) yang juga menemukan pita serapan dari $\mathrm{OH}$ muncul pada bilangan gelombang $3572 \mathrm{~cm}^{-1}$, dan posphat pada 962 dan $630 \mathrm{~cm}^{-1}$. Pita serapan dari karbonat muncul pada bilangan gelombang $1456 \mathrm{~cm}^{-1 "}$.

\section{Analisis morfologi hidroksiapatit menggunakan (SEM)}

Analisis Scanning Electron Microscopy (SEM) digunakan untuk mengetahui bentuk dan morfologi dari hidroksiapatit hasil sintesis. Hasil pengaruh waktu kalsinasi yang dilakukan pada suhu $900{ }^{\circ} \mathrm{C}$ dengan waktu 120 dan 180 menit dapat dilihat pada Gambar 4. Hasil analisis morfologi hidroksiapatit dapat dilihat pada Gambar 4.a, yang menunjukkan bahwa hidroksiapatit (HAp) yang telah disintesis menunjukkan morfologi membentuk granular mendekati bola. "Menurut Wang et al. (2010) partikel HAp seperti bola akan terbentuk pada $\mathrm{pH}$ 10" sedangkan pada Gambar 4.b dapat dilihat bahwa hidroksiaptit (HAp) yang telah disintesis membentuk gumpalan yang tidak 
seragam. Variasi pemanasan atau kalsinasi pada hidroksiapatit mempengaruhi morfologi hidroksiapatit yang diperoleh.

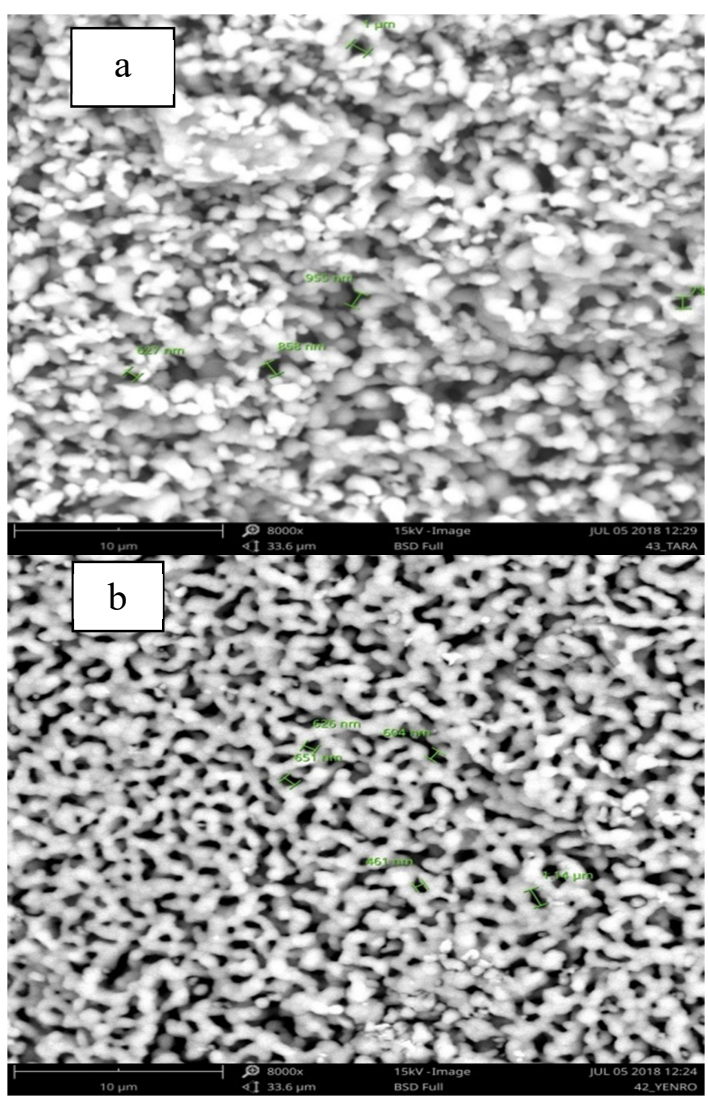

Gambar 4. Mikrograf SEM dari hidroksiapatit yang disintesis menggunakan prekursor $\mathrm{Ca}\left(\mathrm{NO}_{3}\right)_{2}$ dan $\mathrm{H}_{3} \mathrm{PO}_{4}$ pada temperatur kalsinasi $900^{\circ} \mathrm{C}$ selama 120 menit (a) dan 180 menit (b).

\section{KESIMPULAN}

Berdasarkan penelitian yang telah dilakukan dapat disimpulkan bahwa hidroksiapatit (HAp) berhasil disintesis dari cangkang lokan (Geloina coaxans) dan $\mathrm{H}_{3} \mathrm{PO}_{4}$ dengan variasi waktu kalsinasi suhu $900^{\circ} \mathrm{C}$ selama 120 dan 180 menit yang dibuktikan dengan hasil analisis X-Ray Diffraction (XRD). Puncak spesifik hidroksiapatit telah ditunjukkan dengan munculnya puncak khas hidroksiapatit pada $2 \theta=31,7$. Hasil sintesis juga diperkuat dengan analisis menggunakan FTIR yang juga telah menunjukkan adanya pita serapan yang khas hidroksiapatit yaitu adanya gugus $\mathrm{OH}$ dan $\mathrm{PO}_{4}{ }^{3}$. Analisis morfologi menggunakan SEM menunjukkan morfologi hidroksiapatit berbentuk granula bola dan gumpalan yang tidak seragam.

\section{DAFTAR PUSTAKA}

Abidi, S. \& Murtaza, Q. 2013. Synthesis and characterization of nano-hydroxyapatite powder using wet chemical precipitation reaction. Journal Material Science Technology. 3, 1 - 4.

Chen, J. Wen, Z. Zhong, S. Wu, J and Zhang, Q. 2015. Sythesis of hydroxyapatite nanorods from abalone shells via hydrothermal solid-state conversion. Materials and Design. 87, 445-449.

Kamalanathan, P. Ramesh, S. Bang, LT. Niakan, A. Tan, CY. Purbolaksono, J. Chandran, H. Teng, WD. 2014. Synthesis and sintering of hidroxyapatite derived from egg shells as a calcium precursor. Ceramic International. 40(10), 16349-16359.

Khoo, W. Nor, FM. Ardhyananta' H. \& Kurniawan, D. 2015. Preparation of Natural Hydroxyapatite from bovine femur bones using calcination at various temperatures. Procedia Manufacturing. 2, $196-201$.

Koutsopolous, S. 2002. Synthesis and characterization of HAp crystals. Department Of Chemistry, University Of Patras, GR-26500 Patras, Greece.

Liu, J. Matinlinna, JP. Chen, Z. Ning, C. Ni, G. Pan, H. \& Darvell, BW. 2016. Effect of thermal treatment on carbonated hydroxyapatite: Morphology, composition, crystal characteristics and solubility. Ceramic International. 41, 6149-6157.

Shavandi, A. Bekhit, AE. Ali, Z. \& Sun, Z. 2014. Synthesis of nano hydroxyapatite from waste mussel shells using a rapid microwave method. Journal material chemistry and physics. 149-150, 607616.

Sofronia, A.M, Baies, R, Anghel, E.M, Marinescu,C.A. \& Tanasescu, S. 2014.Thermal and structural characterization of synthetic and natural nanocrystalline hydroxyapatite. Materials Science and Engineering $C$. 43, 153-163.

Wang, P, Li, C, Gong, H, Jiang, X, Wang, H. \& $\mathrm{Li}, \quad$ K. 2010. Effects of synthesis conditions on the morphology of hydroxyapatite nanoparticles produced by wet chemical process. Powder Technology. 203(2), 315-321. 